\title{
PERBANDINGAN METODE FTS DAN MA PADA PERAMALAN PERSEDIAAN BERAS
}

\author{
Deddy Kusbianto Purwokoaji ${ }^{1}$, Agung Pramudhita² ${ }^{2}$ Nurhalimah $^{3}$ \\ 1,2,3 Teknik Informatika, Teknologi Informasi, Politeknik Negeri Malang \\ ${ }^{1}$ deddy_kusbianto@polinema.ac.id , ${ }^{2}$ agung.pramudhita@polinema.ac.id,33 nurhalimahakn2@gmail.com
}

\begin{abstract}
Abstrak
Dalam memenuhi kebutuhan masyarakat Kabupaten Malang dan menjaga stabilitas ketersediaan beras pemerintah setempat perlu melakukan proses peramalan. Dimana dalam melakukan proses peramalan menggunakan metode peramalan, salah satunya dengan menggunakan metode Fuzzy Time Series dan Moving Average yaitu dengan menangkap pola dari data yang telah lalu kemudian digunakan untuk memproyeksikan data yang akan datang. Dari hasil implementasi dua metode tersebut menghasilkan perbandingan jumlah persediaan beras. hasil perbandingan tersebut akan dipakai untuk mengukur tingkat error dari masing - masing metode dengan menggunakan MAD (Mean Absolute Deviation), MSE (Mean Square Error), RMSE ( Root Square Error ) dan MAPE (Mean Absolute Percentage Error). Kesimpulannya adalah metode fuzzy time series cocok digunakan untuk studi kasus peramalan persediaan beras dibandingkan menggunakan metode moving average. Sehingga untuk proses peramalan selanjutnya dan untuk mendapatkan hasil dengan tingkat error sedikit dapat menggunakan metode fuzzy time series.
\end{abstract}

Kata kunci : persediaan beras, peramalan, fuzzy time series, moving average

\section{Pendahuluan}

Pangan merupakan kebutuhan dasar manusia yang paling utama dan pemenuhannya merupakan hak asasi manusia terutama dalam hal menjaga stabilitas ketersediaan terutama persediaan bahan makanan pokok dalam hal ini adalah persediaan beras mengingat perubahan iklim yang tidak mampu sepenuhnya dapat diantisipasi dengan baik, selain itu ada beberapa hal yang dapat mempengaruhi jumlah ketersediaan persediaan beras selain iklim yang tidak mampu diantisipasi yaitu meningkatnya konsumsi masyarakat setempat yang mana setiap tahunnya populasi masyarakat bertambah otomatis kebutuhan masyarakatpun bertambah selain itu ada juga faktor luas panen yang mana setiap tahunnya mengalami penyusutan dikarenakan proses perkembangan pertumbuhan kabupaten malang yang berpengaruh terhadap tingkat produksi beras di kabupaten malang.

Sehingga masalah yang dihadapi kedepannya adalah pemerintah setempat mampu meningkatkan jumlah produksi untuk bisa menyediaakan persediaan beras yang berkecukupan dan berkelanjutan. Dari masalah tersebut dibutuhkan suatu data yang menunjukan persediaan beras dari tahun ke tahun agar ketersediaannya dapat terpantau dan memenuhi kebutuhan masyarakat setempat.

Data hasil tahun ketahun tersebut membutuhkan proses peramalan diamana dalam melakukan proses peramalan menggunakan metode peramalan. Salah satunya dengan menggunakan metode Fuzzy Time Series dan Moving Average. Metode Fuzzy Time Series ini merupakan metode yang menangkap pola dari data yang telah lalu kemudian digunakan untuk memproyeksikan data yang akan datang sedangkan metode Moving Average merupakan metode peramalan yang dilakukan dengan mengambil sekelompok nilai pengamatan lalu merata - ratakan dimana akan digunakan sebagai ramalan untuk periode berikutnya.

Sehingga untuk mengetahui metode mana yang cocok digunakan untuk proses peramalan persediaan beras dilakukanlah proses peramalan dengan membandingkan metode Fuzzy Time series dan Moving average.

\section{Tinjauan Pustaka}

\subsection{Persediaan Beras}

Beras merupakan salah satu jenis pangan yang merupakan makanan pokok masyarakat indonesia khususnya masyarakat kabupaten malang. Yang dimaksud dengan Persediaan beras merupakan sejumlah persediaan yang tersimpan di dalam gudanggudang yang berada di bawah pemantauan dinas ketahanan pangan kabupaten malang yang dipergunakan untuk memenuhi kebutuhan masyarakat setempat. Ada beberapa faktor yang dapat mempengaruhi jumlah ketersedian beras di kabupaten malang yaitu, luas panen, kebutuhan masyarakat yang dipengaruhi oleh jumlah konsumsi masyarakat dan jumlah masyarakat / penduduk, dan yang terakhir adalah jumlah produksi.

Jumlah persediaan beras yang yang terdapat di Dinas ketahanan pangan kabupaten malang diperoleh 
dari jumlah produksi setiap panennya dan jumlah kebutuhan masyarakat setempat. Proses pengambilan data persediaan beras di Dinas ketahanan pangan kabupaten malang dilakukan dengan melakukan observasi yaitu dengan cara pengumpulan data yang sesuai dan yang diperlukan, data yang digunakan yaitu data persediaan beras untuk tahun 2013 sampai dengan tahun 2018 seperti yang terlihat pada tabel 1 .

Tabel 1. data persediaan beras 2013-2018

\begin{tabular}{|c|c|c|c|c|c|c|c|}
\hline \multirow[t]{2}{*}{ no } & \multirow[t]{2}{*}{ Bulan } & \multicolumn{6}{|c|}{ Tahun } \\
\hline & & 2013 & 2014 & 2015 & 2016 & 2017 & 2918 \\
\hline 1 & Januari & 30376.25 & 28680 & 27951.4 & 25224 & 25817.5 & $18,6,1.1$ \\
\hline 2 & Februari & 30376.25 & 28680 & 27951.4 & 25224 & 25817.5 & 23,406 \\
\hline 3 & Maret & 30376.25 & 28680 & 27951.4 & 20272.3 & 25817.5 & 42,449 \\
\hline 4 & April & 30376.25 & 28680 & 27951.4 & 20272.3 & 25817.5 & $40,89 u$ \\
\hline 5 & Mei & 22295.5 & 25791 & 27951.4 & 20272.3 & 25817.5 & 27,876 \\
\hline 6 & Juni & 22295.5 & 25791 & 47454 & 20272.3 & 25817.5 & 23,446 \\
\hline 7 & Juli & 22295.5 & 20491.25 & 19903 & 20272.3 & 25817.5 & 30,734 \\
\hline 8 & Agustus & 22295.5 & 20491.25 & 21868 & 20272.3 & 25817.5 & 24,649 \\
\hline 9 & September & 21540 & 20491.25 & 23108 & 33172.25 & 25817.5 & 19,724 \\
\hline 10 & Oktober & 21540 & 20491.25 & 20189 & 33172.25 & 25817.5 & 22,235 \\
\hline 11 & November & 21540 & 20491.25 & 17916 & 33172.25 & 25817.5 & 21,156 \\
\hline$\overline{12}$ & Desember & 21540 & 20491.25 & 12489 & 33172.25 & 25817.5 & 17,904 \\
\hline
\end{tabular}

Sumber : Hasil Observasi pada Dinas Ketahanan Pangan Kabupaten Malang.

Jenis data diatas dapat dikatakan sebagai jenis data time series yang dimana meliputi beberapa periode waktu yaitu bulanan yang mana dipengaruhi oleh pola musiman misalnya kuartal tahun tertentu ataupun bulan tertentu seperti yang terlihat pada data diatas. Proses produksinya dipengaruhi seberapa banyak hasil panen setiap musimnya sehingga berpengaruh pada jumlah data yaang setiap bulannya memiliki jumlah persediaan beras yang sama hal ini disebabkan oleh hasil panennya berdasarkan pola musiman kuartal tahunan dan beberapa bulan kedepan sehingga dikalkulasikan pertahun ataupun seperempat bulan sekali sesuai produksinya, karena proses peramalan dilakukan dengan menggunakan data perbulannya untuk data 6 tahun yaitu 2013 - 2018 sehingga penulis membagi persediaan beras ke dalam beberapa periode tertentu (perbulan).

\subsection{Peramalan}

Peramalan merupakan suatu kegiatan untuk memperkirakan suatu kejadian apa yang akan terjadi pada masa yang akan datang. Peramalan dapat dikatakan sebagai awal dari sebuah proses pengambilan keputusan. Sebelum melakukan sebuah peramalan, hendaknya harus diketahui dahulu apa maksud dan tujuan dari melakukan peramalan. Pada dasarnya, peramalan merupakan pemikiran terhadap sesuatu yang akan datang. Contohnya adalah permintaan terhadap suatu produk pada periode waktu yang akan datang. Pada hakekatnya, sebuah peramalan hanya merupakan suatu perkiraan terhadap suatu objek. Akan tetapi, dengan menggunakan teknik peramalan yang tepat maka peramalan akan menjadi lebih dari sekedar perkiraan. Pada umumnya, hasil peramalan yang baik dapat dilihat dari kecilnya nilai kesalahan meramal atau forecast error yang dapat diukur dengan menggunakan Mean Absolute Deviation, Mean Square Error, Root Mean Square Error dan Mean Absolute Percentage Error. C. Iswahyudi (2016)

\subsection{Fuzzy Time Series}

Fuzzy time series adalah metode peramalan data yang menggunakan prinsip - prinsip fuzzy sebagai dasarnya. Sistem permalan dengan Fuzzy time series angkap pola dari data yang telah lalu kemudian nakan untuk memproyeksikan data yang akan ng. Berikut contoh perhitungan manual Metode y Time Series : M. S. Haris (2017)

Input data peramalan tahun $2013-2018$.

Menentukan himpunan semesta (Universe of discourse $U$ ) dari data historis dengan mencari nilai maksimum dan minimum dari data historis $(\mathrm{U}=[\mathrm{Dmax}, \mathrm{Dmin}])$.

Hitung Interval efektif dengan menggunakan metode berbasis rata - rata.

- $\quad$ Bagi Universe of discourse $U$ dengan beberapa seling seri data U1, U2....,Un, dan tentukan nilai linguistic. Misalkan $U=[13000,20000]$ bisa dibagi menjadi tujuh interval u1, u2, u3, u4, u5, u6, u7 dimana u1 $=[13000,14000], \mathrm{u} 2=$ $[14000,15000]$, u3 $=[15000,16000]$, u4 $=$ $[16000,17000], \mathrm{u} 5=[17000,18000], \mathrm{u} 6=$ [18000,19000], u7 = [19000,20000]. Selanjutnya Jadikan A1, A2, ..., Ak menjadi suatu himpunanhimpunan fuzzy yang variabel linguistiknya ditentukan sesuai dengan keadaan semesta.

- Fuzzifikasi nilai dari data histori, dimana proses mengidentifikasi data aktual ke dalam fuzzy set. Fuzzifikasi di notasikan sebagai berikut, jika F(t1) berada pada himpunan fuzzy set Ak maka F(t1) akan difuzzifikasikan sebagai Ak. seperti yang terlihat pada tabel berikut :

Tabel 2. Fuzzifikasi data historis

\begin{tabular}{|c|c|c|}
\hline Year & $\begin{array}{c}\text { Actual } \\
\text { Enrollment }\end{array}$ & $\begin{array}{c}\text { Fuzzified } \\
\text { Enrollment }\end{array}$ \\
\hline 1971 & 13055 & A1 \\
\hline 1972 & 13563 & A1 \\
\hline 1973 & 13867 & A1 \\
\hline 1974 & 14696 & A2 \\
\hline 1975 & 15460 & A3 \\
\hline 1976 & 15311 & A3 \\
\hline 1977 & 15603 & A3 \\
\hline
\end{tabular}

- Menentukan Fuzzy Logical Relationship (FLR) dari hasil fuzzifikasi, berdasarkan suatu nilai fuzzifikasi dari data historis. jika variabel time series $F(t-1)$ difuzzifikasi sebagai Ai dan $F(t)$ sebagai $\mathrm{Aj}$, maka $\mathrm{Ai}$ beralasi $\mathrm{Aj}$ yanag dapat dinyatakan dengan notasi $\mathrm{Ai}$-> Aj. Seperti yang terlihat pada tabel berikut : 
Tabel 3. Contoh FLR

\begin{tabular}{|l|l|l|}
\hline A1 $\rightarrow$ A1 & A1 $\rightarrow$ A1 & A1 $\rightarrow$ A2 \\
\hline A2 $\rightarrow$ A3 & A3 $\rightarrow$ A 3 & A3 $\rightarrow$ A3 \\
\hline
\end{tabular}

- Maka bisa diperoleh fuzzy logical relationship, dimana fuzzy logical relationship $\mathrm{Aj}$-> Ak berarti jika nilai pada tahun i adalah Aj maka pada tahun i+1 adalah Ak. Aj sebagai sisi kiri relationship disebut sebagai current state dan Ak sebagai sisi kanan relationship disebut sebagai next state. Dan jika terjadi perulangan hubungan maka tetap dihitung sekali.

- Menentukan Fuzzy Logical Relationship Group (FLRG), mengklasifikasi FLR yang telah diperoleh dari tahap sebelumnya ke dalam grup grup sehingga terbentuklah Fuzzy Logical Relationship Group (FLRG) menjadi beberapa bagian berdasarkan sisi kiri (current state). Seperti yang terlihat pada tabel berikut :

Tabel 4. Contoh FLRG

\begin{tabular}{|l|l|}
\hline Group 1 & A1 $>$ A1 $\rightarrow$ A2 \\
\hline Group 2 & A2 $>$ A3 \\
\hline Group 3 & A3 $>$ A3 $>$ A3 \\
\hline
\end{tabular}

- $\quad$ Prediksi FLRG dan difuzzifikasi prediksi.

Untuk tahun 1972, karena hasil fuzzifikasi pendaftaran tahun 1971 pada tabel 1 adalah $A 1$, dan dari tabe 3 bisa dilihat bahwa terdapat fuzzy logical relationship group dengan $A 1$ sebagai current state sebagai berikut : $A 1 \rightarrow A 1, A 2$ di mana nilai keanggotaan maksimum untuk himpunan fuzzy $A 1$ dan $A 2$ terjadi pada interval $u 1$ dan $u 2$, dengan $u 1=$ [13000,14000] dan $u 2=[14000,15000]$, serta nilai tengah dari interval $u 1$ dan $u 2$ adalah 13500 dan 14500 . Maka untuk meramalkan jumlah pendaftar pada tahun 1972 adalah $(13500+14500) / 2=14000$.

\subsection{Moving Average}

Dalam statistik, rata-rata bergerak (moving average atau running average) adalah perhitungan untuk menganalisis poin data dengan membuat serangkaian rata-rata dari himpunan bagian yang berbeda dari kumpulan data lengkap. Ini juga disebut moving average (MA) atau rolling mean dan merupakan jenis filter respon impuls terbatas.

Rumus Moving Average atau Rata-rata Bergerak adalah sebagai berikut : R. Rachman and M. Average (2018)

$\mathrm{MA}=\sum \mathrm{X} /$ jumlah

Keterangan :

MA : Moving Average

$\Sigma X$ : Keseluruhan Penjumlahan dari semua data periode waktu yang diperhitungkan Jumlah Periode : Jumlah Periode Rata-rata bergerak

\subsection{Interval Berbasis Rata - Rata}

Interval berbasis rata - rata berpengaruh dalam penentuan jumlah himpunan fuzzy yang digunakan dalam proses prediksi dengan menggunakan metode Fuzzy Time series. Langkah - langkah untuk menentukan interval adalah sebagai berikut:

- Hiting seluruh selisih absolute antara Dt-1 dan Dt $(\mathrm{t}=1, \ldots, \mathrm{n})$. Dimana $\mathrm{D}$ merupakan data aktual dan $\mathrm{t}$ merupakan periode.

- Menghitung nilai rata - rata hasil kalkulasi seluruh selisih absolute.

- Ambil setengah nilai rata - rata absolute.

- Berdasarkan nilai yang diperoleh pada langkah ke "c", ditetapkan basis nilai tersebut sesuai pada tabel 2.4.

Tabel 5. Basis Interval

\begin{tabular}{|c|c|}
\hline Jangkauan & Basis \\
\hline $0.1-1.0$ & 0.1 \\
\hline $1.1-10$ & 1 \\
\hline $11-100$ & 10 \\
\hline $101-1000$ & 100 \\
\hline $1001-10000$ & 1000 \\
\hline $10001-100000$ & 10000 \\
\hline
\end{tabular}

- Bulatkan nilai yang diperoleh sesuai dengan basis yang ada pada tabel diatas. Y. Ekananta, dkk (2018)

\subsection{Ukuran Ketepatan Suatu Metode}

Keakuratan dan ketepatan dari sebuah hasil peramalan mempunyai peran penting dalam sebuah perusahaan terlepas dari apapun proses bisnis yang ada. Kesalahan ramalan menyebabkan perencanaan menjadi tidak akurat, sehingga kesalahan tersebut menyebabkan resiko, dan karenanya harus diusahakan sekecil mungkin. Hasil dari peramalan diharapkan mampu memberikan gambaran yang mendekati kenyataan di lapangan. Ketepatan dan keakuratan tersebut dapat dinyatakan sebagai akurasi kesalahan dalam peramalan. Keakuratan hasil ramalan dari suatu metode dapat dihitung dengan beberapa cara, yaitu sebagai berikut : D. Isi (2018)

\section{- $\quad$ MAD (Mean Absolute Deviation)}

MAD adalah rata rata kesalahan mutlak selama periode tertentu tanpa memperhatikan apakah hasil peramalan lebih besar atau lebih kecil dibanding kenyataannya, dengan kata lain MAD adalah rata-rata dari nilai absolut simpangan. Secara sistematis MAD dirumuskan sebagai berikut :

$\operatorname{MAD}=\left(\sum_{\_}(\mathrm{t}=1)^{\wedge} \mathrm{n}|\mathrm{At}-\mathrm{Ft}| / \mathrm{n}\right.$ 


\section{- $\quad \operatorname{MSE}$ (Mean Square Error)}

MSE dihitung dengan menjumlahkan kuadrat semua kesalahan peramalan pada setiap periode dan membaginya dengan jumlah periode peramalan. Secara sistematis MSE dirumuskan sebagai berikut :

$$
\operatorname{MSE}=\left(\sum \_(t=1)^{\wedge} \mathrm{n} \llbracket(\text { At-Ft }) \rrbracket^{\wedge} 2 / \mathrm{n}\right.
$$

\section{- $\quad$ RMSE (Root Mean Square Error)}

Ukuran ini digunakan untuk membandingkan akurasi antara dua atau lebih model. Semakin kecil nilai RMSE suatu model menandakan semakin akurat model tersebut.

$$
\operatorname{RMSE}=\sqrt{ }\left(\left(\sum \_(\mathrm{t}=1)^{\wedge} \mathrm{n} \llbracket(\mathrm{At}-\mathrm{Ft}) \rrbracket^{\wedge} 2 / \mathrm{n}\right.\right.
$$

- MAPE (Mean Absolute Percentage Error) Mean Absolute Percentage Error rmerupakan ukuran kesalahan relatif. MAPE biasanya lebih berarti dibandingkan MAD karena MAPE menyatakan persentase kesalahan hasil peramalan terhadap permintaan aktual selama periode tertentu yang akan memberikan informasi persentase kesalahan terlalu tinggi atau terlalu rendah, dengan kata lain MAPE merupakan ratarata kesalahan mutlak selama periode tertentu yang kemudian dikalikan 100\% agar mendapatkan hasil secara prosentase. Secara sistematis MAPE dirumuskan sebagai berikut:

$$
\operatorname{MAPE}=\left(\sum \_(\mathrm{t}=1)^{\wedge} \mathrm{n}(|\mathrm{At}-\mathrm{Ft}|) / \mathrm{At}\right) / \mathrm{n} * 100
$$

\section{Metodelogi Penelitian}

Metode pengembangan yang digunakan adalah Waterfall atau yang sering dinamakan siklus hidup klasik (classic life cycle), dimana hal ini menggambarkan pendekatan yang sistematis dan juga berurutan pada pengembangan perangkat lunak, dimulai dengan spesifikasi kebutuhan pengguna lalu berlanjut melalui tahapan-tahapan perencanaan (planning), permodelan (modeling), konstruksi (construction), serta penyerahan sistem ke para pelanggan/pengguna (deployment), yang diakhiri dengan dukungan pada perangkat lunak lengkap yang dihasilkan

Metode pengambilan data yang digunakan adalah metode observasi. Pengumpulan data dilakukan sesuai dengan sumber dan jenis data yang diperlukan. Pengumpulan data kuantitatif dalam penelitian ini dilakukan dengan menggunakan data persediaan beras yang terdapat pada Dinas Ketahanan Pangan Kabupaten Malang yang berupa Excel.

Pengujian dilakukan berdasarkan spesifikasi sistem. Pengujian spesifikasi sistem yang dilakukan meliputi pengujian kesesuaian proses, pengujian kesesuaian atau tingkat akurasi dan pengujian kecepatan waktu dari kedua metode diatas. Pengujian dilakukan dengan Black Box Testing dimana pengujian dilakukan hanya mengamati hasil eksekusi melalui data uji dan memeriksa fungsional dari perangkat lunak.

\section{Perancangan}

\subsection{Deskripsi Sistem}

Sistem informasi peramalan persediaan beras menggunakan dua metode yaitu Fuzzy Time Series dan Moving Average adalah sebuah sistem yang bertujuan untuk menganalisa metode tersebut dengan memprediksi persediaan beras pada periode berikutnya dan juga dapat mempersiapkan berapa persediaan yang tersedia untuk periode selanjutnya dengan akurat mengacu pada data masalalu. Data - data persediaan beras periode yang lalu atau data Histori dapat dimanfaatkan sebagai input bagi analisa persediaan beras di Dinas Ketahanan Pangan Kabupaten Malang

\subsection{Analisa Kebutuhan Fungsional}

Kebutuhan fungsional pada sistem atau layanan dalam aplikasi yang harus disediakan, serta gambaran proses dari sistem terhadap masukan sistem dan yang akan dijalankan adalah sebagai berikut :

- Sistem mampu mengelola data persediaan beras.

- Sistem mampu menyediakan fasilitas perhitungan untuk menghitung peramalan persediaan stok beras.

- Sistem mampu menghasilkan laporan terkait jumlah persediaan stok beras untuk beberapa tahun kedepan.

\subsection{Use Case Diagram}

Struktur menu aplikasi System analisis peramalan persediaan beras dengan metode moving average dan fuzzy time series dengan pemrograman PHP. Diagram use case mendeskripsikan sebuah interaksi antara satu atau lebih actor dengan System yang akan dibuat. Berikut Use Case diagram aplikasi disajikan pada gambar dibawah ini.

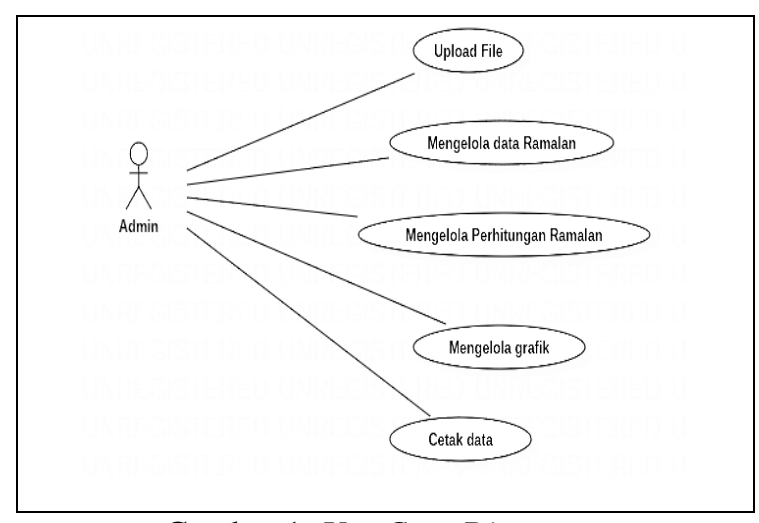

Gambar 1. Use Case Diagram 


\subsection{Flowchart}

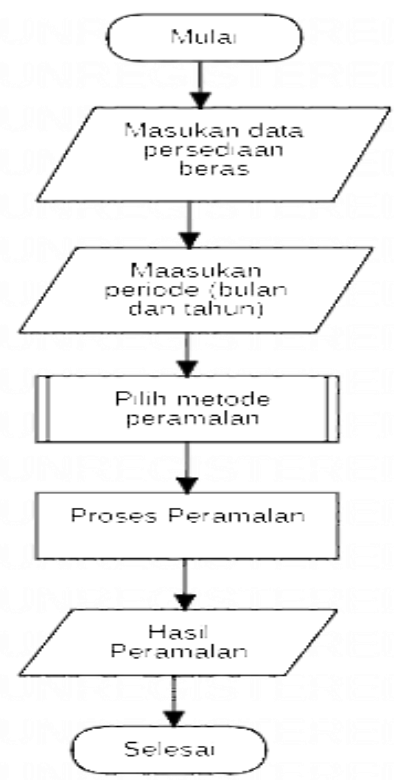

Gambar 2. Flowchart Diagram

Gambar dibawah adalah gambar flowchart alur sistem dari sistem informasi analisis peramalan persediaan beras di Dinas Ketahanan Pangan Kabupaten Malang. Flowchart Alur Sistem informasi analisis peramalan persediaan beras dengan metode Fuzzy Time Series dan Moving Average dengan menginput data, yaitu data persediaan beras pada periode sebelumnya agar dapat dilakukan peramalan. Karena untuk melakukan perhitungan peramalan, data yang ada pada periode sebelumnya digunakan sebagai input untuk proses perhitungan. Kemudian input berupa data persediaan beras pada periode $2013-2017$ sebelumnya oleh sistem akan dilakukan proses perhitungan peramalan dengan menggunakan metode Fuzzy Time Series dan Moving Average.

Hasil output berupa laporan data persediaan beras untuk bulan berikutnya yaitu di tahun 2018 lalu membandingkan hasil peramalan dengan data real tahun 2018 sehingga dapat di analisa metode mana yang lebih mendekati dengan data realnya.

\section{Implementasi}

\subsection{Implementasi Aplikasi}

Implementasi aplikasi dilakukan dengan mengacu perancangan aplikasi yang telah dibuat sebelumnya. Implementasi aplikasi memuat berbagai uraian mengenai data, membuat program, dan interface dari Sistem Informasi Analisis Metode Fuzzy Time Series dan Moving Average pada data aktual 2018 persediaan beras di Dinas Ketahanan Pangan Kabupaten Malang berdasarkan perancangan yang dibuat sebelumnya.

\subsection{Implementasi Sistem}

Pada bagian ini merupakan hasil implementasi dari hasil rancangan interface dari sistem yang telah dirancang.

- Halaman Data peramalan

Halaman Data peramalan menampilkan informasi tentang data peramalan persediaan beras tahun 2013 - 2018 yang akan dijadikan sebagai data untuk prediksi, tampilan halaman data peramalan persediaan beras tahun 2013 - 2018 dapat dilihat pada gambar 5 .

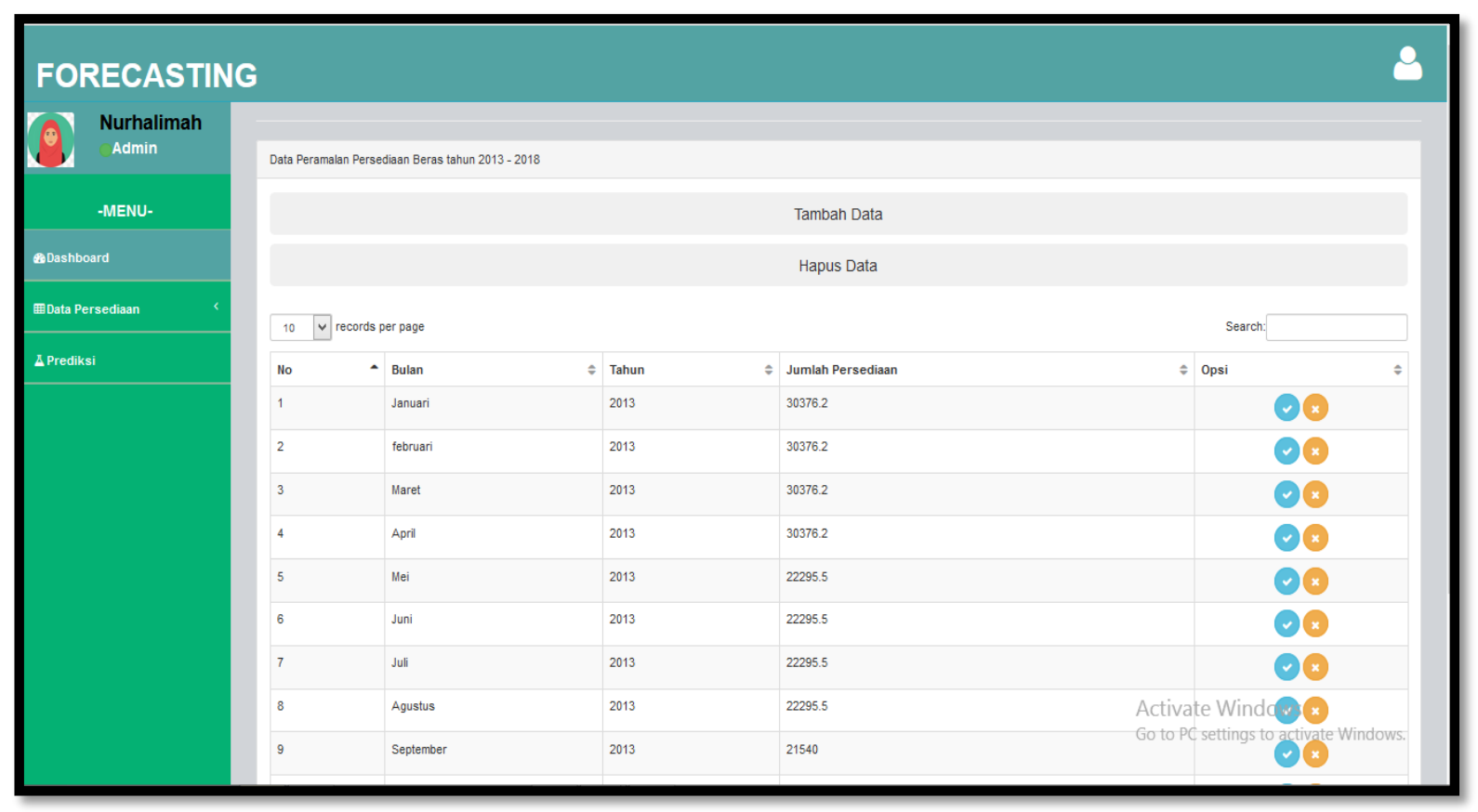

Gambar 3. Halaman data peramalan 
- Halaman Prediksi

Implementasi selanjutnya adalah pengujian pada proses perhitungan dua metode peramalan, pada halaman ini terdapat fitur dropdown yaitu nama metode peramalan, fitur data yang akan dugunakan dan fitur cetak serta button hitung untuk proses peramalan. Sebelum masuk ke proses perhitungan, admin terlebih dahulu memilih metode yang digunakan dan memilih data yang akan diramalkan.
Setelah menentukan metode yang akan digunakan dan data yang akan diramal, admin mengklik button hitung maka proses perhitungan berjalan dan menghasilkan data peramalan sesuai berapa tahun data yang digunakan serta menampilkan jumlah error, tingkat keakuratan serta grafik peramalan. Seperti yang terlihat pada gambar 5 dengan memasukan data 6 tahun peramalan sehingga menghasilkan peramalan tahun 2019.

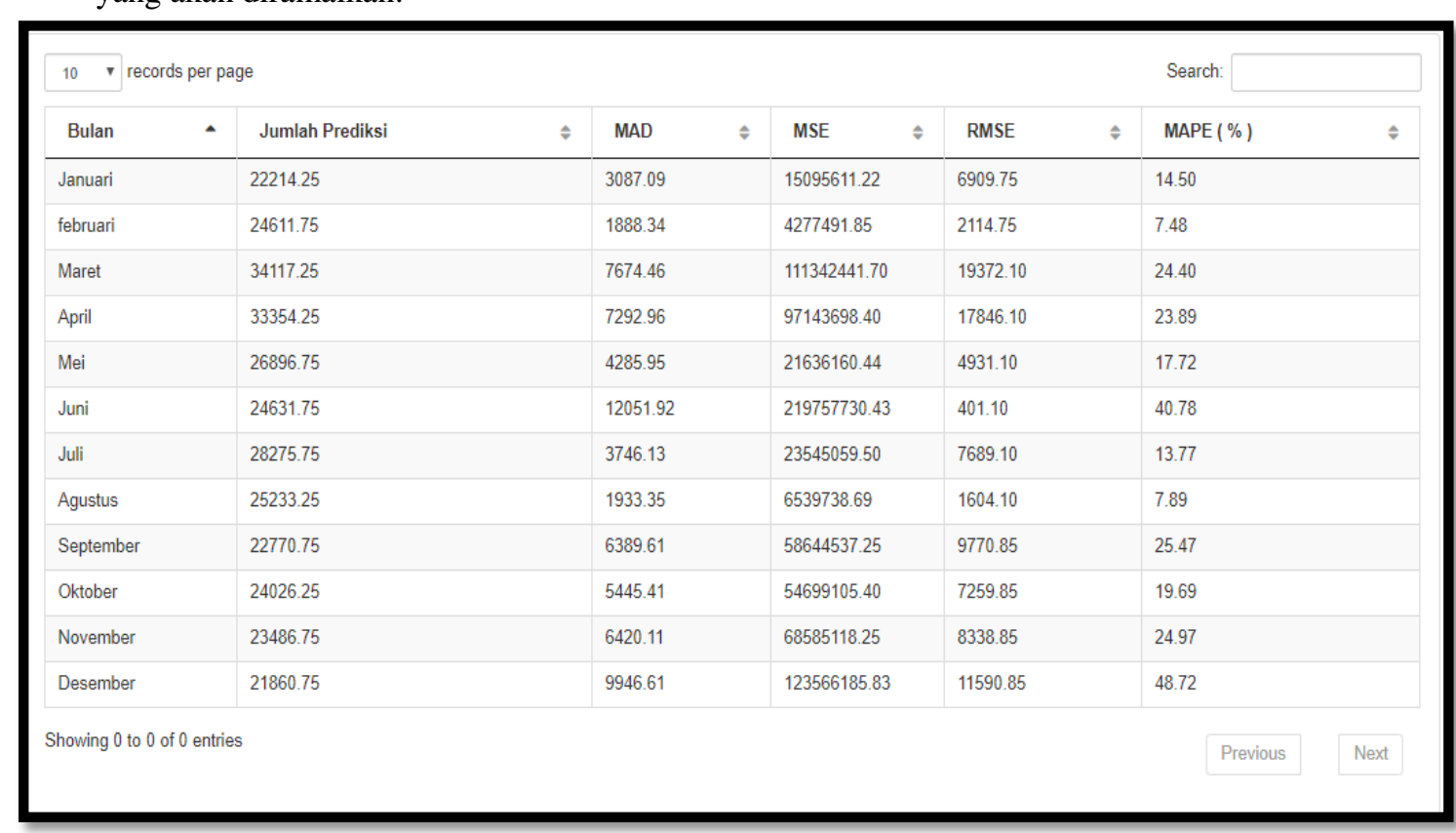

Gambar 4. Halaman prediksi Moving Average

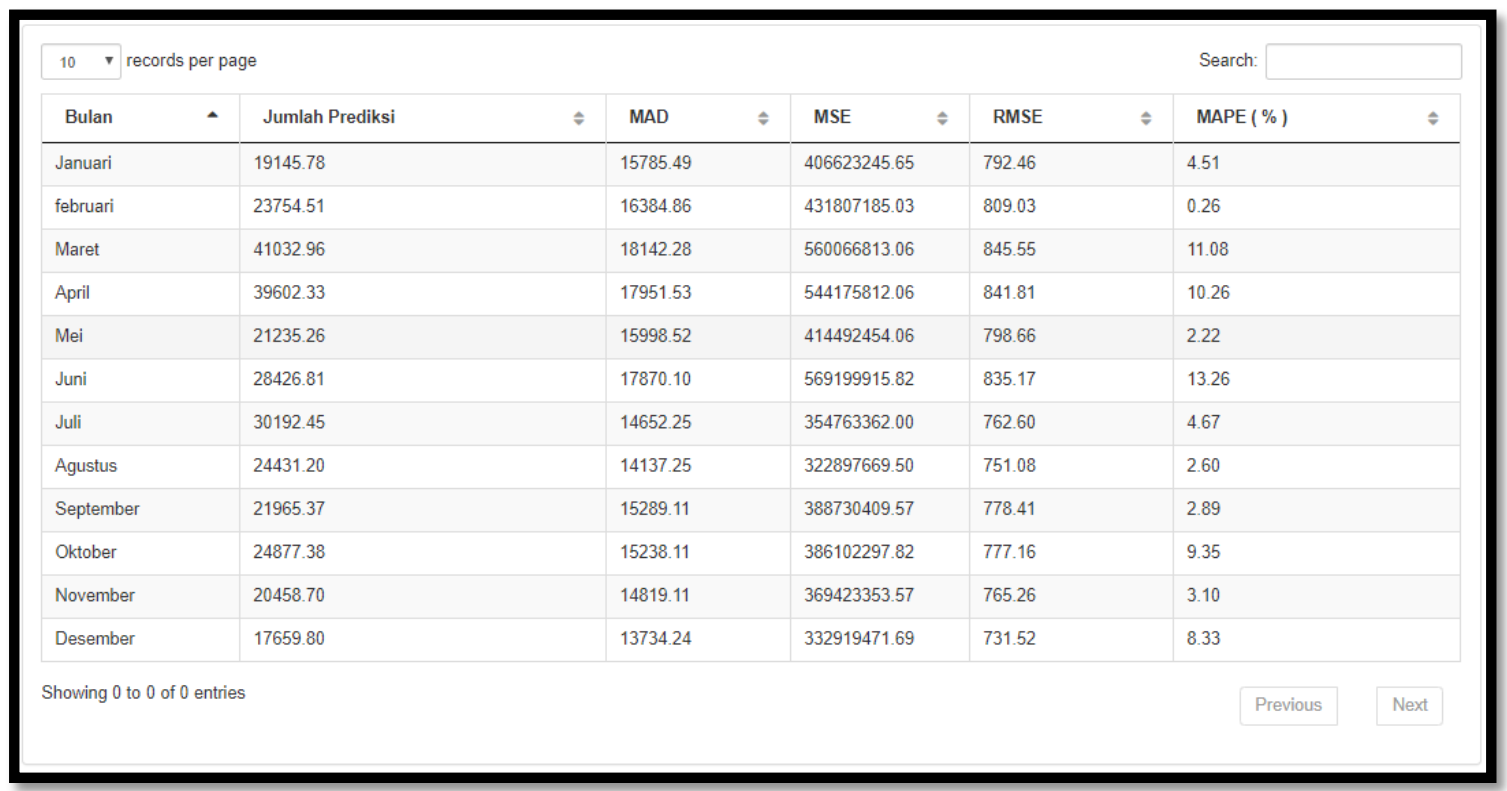

Gambar 5. Halaman prediksi Fuzzy time series 


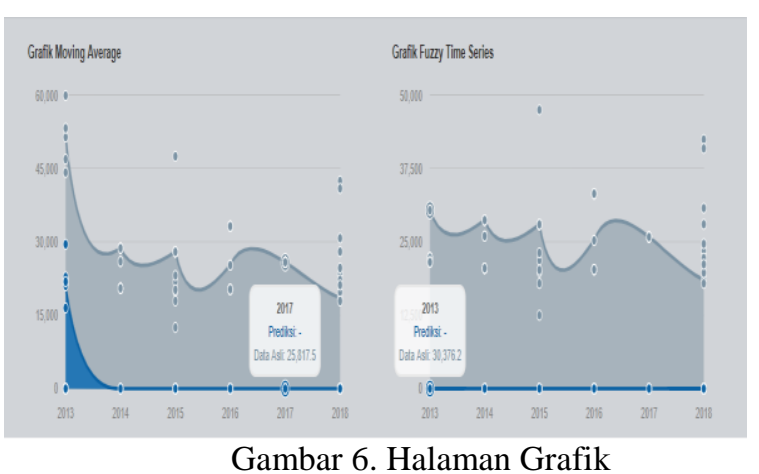

Selanjutnya admin berhasil menampilkan hasil grafik dari proses peramalan persediaan beras.

Halaman grafik menampilkan sejumlah keadaan dari hasil peramalan data persediaan beras pada periode tertentu yaitu menampilkan keterangan metode yang digunakan, periode data yang digunakan, jumlah persediaan dan jumlah peramalan.

\subsection{Hasil Uji Coba}

Berdasarkan pengujian yang telah dilakukan yaitu pada metode fuzzy time series dan moving average dengan menggunakan data persediaan beras tahun 2013 sampai dengan tahun 2018 menunjukan jumlah kesalahan yang berbeda - beda. Berdasarkan data 2013 - 2018 yang telah dilakukan, maka data bisa dikelompokkan menjadi dua yaitu kelompok fuzzy time series dan kelompok moving average.

Berikut adalah hasil keseluruhan data yang dicari mengguankan metode Fuzzy time series beserta jumlah kesalahan yang terdapat dalam peramalan persediaan beras yang proses perhitungan kesalahannya menggunakan MAD, MSE, RMSE dan MAPE. Secara umum jika nilai MAD dan MSE semakin rendah maka berarti semakin baik. Nilai MAD berguna ketika mengukur kesalahan ramalan dalam unit yang sama sebagai deret asli karena semakin kecil nilai MAD, berarti semakin kecil pula perbedaan antara hasil forecasting dan nilai aktual sedangkan MSE mengatur kesalahan peramalan yang besar karena kesalahan - kesalahan itu dikuadratkan. Nilai RMSE menunjukan semakin besar nilai RMSE maka hasil peramalan tidak tepat, sedangkan nilai MAPE dapat dikatakan jika nilai MAPE semakin kecil maka semakin akurat teknik peramalan jika semakin besar nilai MAPE maka semakin tidak akurat.

Berdasarkan prediksi perhitungan metode moving average diperoleh jumlah kesalahan (nilai Error) berturut - turut dari hasil prediksi bulan januari 2019 dampai dengan bulan desember 2019 dengan menggunakan data tahun bulan januari 2013 sampai dengan bulan desember tahun 2018 dengan perbandingan kesalahan dimana data yang menghasilkan jumlah kesalahan lebih kecil maka data tersebut mendekati akurat pada nilai data asli tahun sebelumnya seperti yang terlihat pada tabel 6 .
Tabel 6. Hasil Rata - rata Error

\begin{tabular}{|l|c|c|c|c|c|c|}
\hline \multirow{2}{*}{ Metode } & Tahun & $\begin{array}{c}\text { Mengg } \\
\text { unakan } \\
\text { Data }\end{array}$ & MAD & MSE & RMSE & MAPE \\
\hline $\begin{array}{l}\text { Fuzzy } \\
\text { Time } \\
\text { Series }\end{array}$ & $\mathbf{2 0 1 9}$ & $\mathbf{6}$ tahun & 1511.129 & 423433499.2 & 790.726 & 6.044 \\
\cline { 2 - 7 } & $\mathbf{2 0 1 7}$ & $\mathbf{4}$ tahun & 994.259 & 377952923.7 & 630.803 & 4.340 \\
\hline $\begin{array}{l}\text { Moving } \\
\text { Average }\end{array}$ & $\mathbf{2 0 1 9}$ & $\mathbf{2}$ tahun & 558.575 & 260160821.1 & 311.754 & 2.183 \\
\cline { 2 - 7 } & $\mathbf{2 0 1 7}$ & $\mathbf{4}$ tahun & 5846.828 & 670694006.58 & 8152.375 & 22.44 \\
\cline { 2 - 7 } & $\mathbf{2 0 1 5}$ & $\mathbf{2}$ tahun & & & & \\
& & & 4162.992 & 5483498311660.13 & 2635.517 & 19.567 \\
\hline
\end{tabular}

Sehingga dari hasil rata - rata error pada tabel 6 diperoleh bahwa metode fuzzy time series dapat dikatakan cocok untuk studi kasus peramalan persediaan beras, karena menghasilkan nilai error yang lebih sedikit dibandingkan menggunakan metode moving average, yaitu dengan menggunakan data 6 tahun yaitu dengan perhitungan menggunakan MAD, MSE, RMSE dan MAPE berturut - turut adalah 1511.12917, 423433499.2, 790.725833 dan 6.044166667 , menggunakan data 4 tahun dengan hasil error yaitu 994.2592, 377952923.7, 630.8025, dan 4.34083333, menggunakan data 2 tahun dengan hasil error 558.575, 260160821.1, 311.7542, dan 2.183333.

Sedangkan menggunakan metode Moving Average dapat dikatakan kurang cocok untuk studi kasus peramalan persediaan beras dikarenakan nilai error yang dihasilkan lebih besar dibandingkan menggunakan metode fuzzy time series yaitu menghasilkan nilai error berturut - turut dengan menggunakan data 6 tahun yaitu 5846.828333, 670694006.58, 8152.375, dan 22.44, menggunakan data 4 tahun dengan hasil error yaitu 5078.313, $565311660.13, \quad 2635.51667$ dan 19.5666667, menggunakan data 2 tahun dengan hasil error 4162.992, 548498200.86, 4162.992, 16.14417.

\section{Kesimpulan Dan Saran}

Bab ini memuat elaborasi dan rincian kesimpulan yang dituliskan pada abstrak, saran untuk riset lanjutan.

\subsection{Kesimpulan}

- Hasil dari metode Fuzzy time series dipengaruhi oleh jumlah interval yang mana jumlah interval sudah ditentukan lebih awal pada saat proses perhitungan, penentuan jumlah interval sangat berpengaruh pada proses perhitungan berikutnya.

- Hasil dari metode Moving average hasil peramalan dilakukan dengan cara mencari nilai rata - rata dari suatu data dalam periode tertentu yang akan dijadikan sebagai hasil peramalan di periode yang akan datang.

- Jumlah persedian beras pada Dinas ketahanan pangan kabupaten malang dengan menggunakan metode fuzzy time series menggunakan data 6 tahun menghasilkan rata - rata nilai error dengan menggunakan MAD, MSE, RMSE dan MAPE berturut - turut sebesar adalah 1511.12917, 423433499.2, 790.725833 dan 6.044166667, 
menggunakan data 4 tahun dengan hasil error yaitu 994.2592, 377952923.7, 630.8025, dan 4.34083333, menggunakan data 2 tahun dengan hasil error 558.575, 260160821.1, 311.7542, dan 2.183333

- $\quad$ Sedangkan dengan menggunakan metode moving average yaitu dengan MAD, MSE, RMSE dan MAPE berturut - turut dengan menggunakan data 6 tahun yaitu 5846.828333, 670694006.58, 8152.375 , dan 22.44, menggunakan data 4 tahun dengan hasil error yaitu 5078.313, 565311660.13, 2635.51667 dan 19.5666667, menggunakan data 2 tahun dengan hasil error 4162.992, 548498200.86, 4162.992, 16.14417.

- Dilihat dari perhitungan error yang dihasilkan dengan menggunakan MAD, MSE, RMSE dan MAPE metode fuzzy time series memperoleh nilai error lebih rendah dibandingkan dengan menggunakan metode moving average dengan menggunakan data 2, 4 dan 6 tahun, sehingga metode yang cocok untuk studi kasus peramalan persediaan beras yaitu menggunakan metode Fuzzy time series.

- Dengan menggunakan MAD dan MSE menghslkan nilai error yang lebih besar tetapi pada saat di hitung menggunakan MAPE Presentase error lebih kecil.

\subsection{Saran}

Saran yang penulis dapat sampaikan dan dujadikan bahan pertimbangan dalam pengembangan sistem lebuh lanjut adalah yang pertama dengan menambahkan data persediaan lebih banyak supaya perhitungan lebih akurat dan menghasilkan nilai error lebih sedikit. Dan yang kedua untuk peramalan selanjutnya data yang digunakan lebih bervariasi, bukan hanya 1 komonditi tapi bisa lebih.

\section{Daftar Pustaka}

C. Iswahyudi, "Pengantar Forecasting ( Teknik Peramalan )," 2016.

D. Isi, "Hak Cipta."

M. S. Haris, "Implementasi Metode Fuzzy Time Series Dengan Penentuan Interval Berbasis RataRata Untuk Peramalan Data Penjualan Bulanan," no. September 2017, pp. 1-8, 2010.

R. Rachman and M. Average, "Penerapan Metode Moving Average dan Exponential Smoothing pada Peramalan Produksi Industri Garment," vol. 5, no. 1, pp. 211-220, 2018.

Y. Ekananta, L. Muflikhah, and C. Dewi, "Penerapan Metode Average-Based Fuzzy Time Series Untuk Prediksi Konsumsi Energi Listrik Indonesia," vol. 2, no. 3, pp. 1283-1288, 2018. 